\title{
Terminologia nasycona kulturowo w przekładzie wietnamsko-polskim
}

\section{Culture-bound terminology in Vietnamese- Polish translation}

\author{
Bogdan Nowicki \\ INSTYTUT JĘZYKOZNAWSTWA, UNIWERSYTET IM. ADAMA MICKIEWICZA \\ AL. NIEPODLEGŁOŚCI 4, 61-874 POZNAŃ \\ bognowlamu .edu.pl
}

\begin{abstract}
This article is to explain the basic problems of interpreting Vietnamese culture-bound terminology. The author discusses terminology related to selected customs (including concluding marriages and funerals) as well as selected examples of culture-bound legal terminology. The aim of the apper is to make readers more sensitive to problems of interpreting Vietnamese texts in which words are composed of syllables which are separated with spaces. Therefore, it may be difficult to determine where one word ends, and the other starts in a sentence. The examples provided in the paper may serve as an exemple of potential problems encountered by Vietnamese nonnative speakers.
\end{abstract}

\begin{abstract}
Abstrakt
Artykuł dotyczy podstawowych problemów przekładu wietnamskiej terminologii zanurzonej kulturowo. Autor omawia terminologię dotyczącą wybranych zwyczajów (zawierania związków małżeńskich oraz pogrzebów). Celem pracy jest pokazania, że różnice językowe (fonetyczne $\mathrm{i}$ gramatyczne) oraz kulturowe $\mathrm{w}$ istotny sposób wpływają na proces przekładu, mogąc niedoświadczonego tłumacza zwieść na manowce. By móc skutecznie tłumaczyć teksty z języka wietnamskiego na polski konieczna jest dogłębna znajomość kultury i realiów obu obszarów językowych, gdyż bez niej poprawne zrozumienie komunikatu $\mathrm{w}$ wielu przypadkach jest niemożliwe
\end{abstract}




\section{Wprowadzenie}

Język polski i wietnamski należą do różnych grup językowych, odległych geograficznie i z tego powodu występuje więcej trudności i problemów niż przy tłumaczeniach w ramach jednej grupy językowej. Należy pamiętać, że wietnamski należy do rodziny języków austroazjatyckich i jest językiem tonalnym i izolującym. $Z$ kolei polski należy do rodziny języków indoeuropejskich (grupa języków zachodniosłowiańskich) i jest językiem fleksyjnym.

Ze względu na te różnice problemy tłumaczeniowe możemy pogrupować w następujący sposób:

1. problemy wynikające $\mathrm{z}$ różnic językowych (fonetycznych, gramatycznych i semantycznych) oraz

2. problemy wynikające z różnic religijnych i kulturowych.

\section{Różnice językowe}

Pierwszą grupę trudności stanowią problemy fonetyczne, szczególnie istotne w przekładzie ustnym. Fonetyka języka wietnamskiego dla Polaków jest trudna. O ile nie mamy jako Polacy trudności w powtórzeniu usłyszanych słów niemieckich, włoskich czy angielskich to słowa języka wietnamskiego są tak różne od polskich, że próbując powtórzyć doznajemy uczucia frustracji, nie wiemy jak wyartykułować podobne dźwięki. Powodem tego są różnice na wielu płaszczyznach, wymienię tylko podstawowe kwestie :

1. tonalność: Język wietnamski jest językiem tonalnym, w którym ton stanowi nieodłączną część sylaby, podczas gdy w języku polskim tony wykorzystywane są dla wyrażania emocji,

2. liczba samogłosek. W języku wietnamskim występuje 10 samogłosek, podczas gdy w polskim - tylko 6. Z tej przyczyny występują dwojakiego rodzaju problem, a mianowicie: (i) nie słyszymy różnic między podobnymi samogłoskami (próbujemy umieścić je w zbiorze 6 elementowym) oraz (ii) przy wymawianiu samogłosek (wymawiamy niedokładnie) i są one odbierane przez Wietnamczyków jako inne samogłoski,

3. długość samogłosek. Zjawisko zupełnie nie występujące w języku polskim, a dość powszechne w języku wietnamskim. Różna długość wymawianej głoski powoduje że wymawiamy w odczuciu odbiorcy wietnamskiego - inną sylabę, oczywiście o zupełnie innym znaczeniu (np. tai - długie 'a' znaczenie 'ucho', krótkie 'a' znaczenie 'ręka'),

4. dyftongi ${ }^{1}, \mathrm{w}$ języku polskim występujące sporadycznie, a w języku wietnamskim powszechne.

\footnotetext{
${ }^{1}$ pojedyncza samogłoska (na ogół długa) o zmiennym przebiegu artykulacji, co sprawia, że ucho ludzkie słyszy dwa dźwięki, mimo że są one zespolone niejako w jeden i mają właściwości pojedynczej samogłoski.
} 
Odrębną trudność stanowi gramatyka i ortografia. Fleksja a także określenie kategorii czasu, strony jest realizowana za pomocą słów posiłkowych. Niektóre z nich mają zarówno znaczenie leksykalne, jak i gramatyczne (np. của leksykalnie oznacza 'majątek' a gramatycznie realizuje funkcje dopełniacza). Nie ma podziału na części mowy jak w języku polskim lecz o funkcji słowa decyduje jego pozycja w zdaniu.

W języku wietnamskim występuje tendencja tworzenia słów wielosylabowych, przy zanikaniu słów jednosylabowych. Sylaby w wyrazach wielosylabowych nie są pisane łącznie. Rozdzielność jest reliktem zapisu hieroglificznego który trwał do 1910 r., i stanowi pewną trudność przy określeniu, które sylaby tworzą wyraz.

Kolejną kategorię problemów stanowią problemy leksykalne takie jak:

1. wieloznaczność wynikająca z homonimii i polisemii,

2. synonimia,

3. nieprzystawalność znaczeniowa terminów wietnamskich i polskich.

Jeśli chodzi o problemy wynikające $\mathrm{z}$ wieloznaczności w języku wietnamskim występuję duża liczba homonimów. Słowa mające 2-4 znaczeń są normą, natomiast słowa-rekordziści mogą mieć do 14 znaczeń, a nawet więcej. Powoduje to określone trudności interpretacji tekstu, np słowo đông to 'wschód', 'zima', 'mrożonki, galart', 'tłumny'.

Synonimia wynika $\mathrm{z}$ istnienia równolegle do słów współczesnego języka wietnamskiego również słów sinowietnamskich. Obecność słów sinowietnamskich przejawia się np. w przypadku znaków oznaczających pociąg. który możemy określić używając słów sinowietnamskich tầu hỏa, albo xe lứa, wody terytorialne to vùng biển lub lãnh hải. Liczba 3 jako liczebnik główny lub porządkowy we współczesnym wietnamskim to $b a$ jednak $\mathrm{w}$ słowie trójkąt liczba 3 reprezentowana jest przez sinowietnamskie tam. Występują też odwrotne sytuacje, gdy jedna sylaba może być rozumiana jako słowo sinowietnamskie, lub jako słowo rdzennie wietnamskie, np. słowo bán może być rozumiane w znaczeniu 'sprzedawać' (rdzennie wietnamskiem) albo 'połowa' (sinowietnamskiem).

Przy tłumaczeniu tekstów z języka wietnamskiego mogą pojawiać się problemy $\mathrm{z}$ powodu występowania ciągów synonimiczych. W języku polskim wyrażenia typu „w sumie razem” traktowane są jako błąd językowy, zaś w języku wietnamskim tego rodzaju ciągi synonimiczne występują również w oficjalnych dokumentach. Wietnamskie słowo cấm 'zabraniać' i không được 'nie wolno' bardzo często występują w jednym ciągu tworząc złożenie cấm không được. Analogicznie słowo phong tục 'zwyczaje' i tập quán 'zwyczaje' występują w ciągu phong tục tập quán w znaczeniu 'zwyczaje'. Niedopuszczalna jest jednak zmiana kolejności słów w obu tych ciągach synonimicznych.

Często występuje duża rozbieżność między polami znaczeniowymi słów polskich $\mathrm{i}$ wietnamskich. Istnieją $\mathrm{w}$ języku wietnamskim proste, często spotykane słowa, które wymagają od tłumacza każdorazowo zastanowienia się jak $\mathrm{w}$ danym kontekście oddać to słowo $\mathrm{w}$ języku 
polskim. Ciekawym, powszechnie używanym słowem jest choi. Oznacza czynności wykonywane dla rozrywki, dla zabawy, bez obowiązku, dla przyjemności. W zależności od kontekstu będziemy tłumaczyć je jako: 'iść na spacer', 'przyjść w gości', 'przejść się po sklepach', 'przeglądać gazetę', 'podrywać dziewczynę'.

\section{Różnice kulturowe}

Biorąc pod uwagę odległość geograficzną między Wietnamem i Polską wynoszącą w linii prostej ponad 10 tys. km, mamy prawo oczekiwać dużych różnic kulturowych. Różnice te faktycznie występują i sprawiają tłumaczowi niemałe problemy w procesie translacji. Godny zauważenia jest jednak fakt, że polska i wietnamska historia wykazuje mimo wszystko zdumiewające podobieństwa. Krótki rzut oka na tablice historyczne i porównanie dat pokazuje że oba narody przechodziły w zbliżonym czasie podobne polityczne koleje losu: rozbicie dzielnicowe, naciski wielkiego sąsiada, wojny wyzwoleńcze w XX wieku. Mówiąc o kulturze Wietnamu musimy pamiętać, że w Wietnamie żyje 53 mniejszości narodowe i jedna większość narodowa - rdzenni Wietnamczycy Kinh. Mniejszości narodowe mówią odrębnymi językami, mają własną kulturę, różniące się między sobą stroje, zwyczaje a także sposób budowy domów.

Różnice kulturowe podczas tłumaczenia tekstów $\mathrm{z}$ języka wietnamskiego na polski przejawiają się w terminologii realioznawczej. Występują słowa związane $\mathrm{z}$ życiem codziennym, innym stylem życia. Przykładowo odpowiednikiem polskiego słowa 'ryż' jest 5 terminów w języku wietnamskim, w zależności od stadium rozwoju rośliny: sadzonka przygotowana do posadzeniu na polu to ' $m a$ ', rosnący na polu, zielony ryż to 'lua', wymłócony to 'thóc', przed ugotowaniem to 'gạo', a gotowy do spożycia to 'com'. Prócz tego jest jeszcze słowo na określenie suszonych niedojrzałych (zielonych) nasion ryżu 'cốm'. Prócz tego jest jeszcze słowo na określenie suszonych niedojrzałych (zielonych) nasion ryżu 'cố $m$ '. Pod tym pojęciem rozumiemy miękkie ziarna ryżu otrzymane z przedwczesnego zbioru i po wymłóceniu suszone. Ma specyficzny smak i ceniony jest przede wszystkim ze względu na intensywny zielony kolor. Jest podstawowym składnikiem do wyrobu ciasteczek z zielonego ryżu (m. in. obowiązkowe danie na weselu), lodów (u nas zielone, to pistacjowe lub miętowe - tam: o smaku zielonych ziaren niedojrzałego ryżu, a także jako dodatek do banana - jedząc banana maczamy w tych nasionach każdy kęs. Tłumaczenie na język polski słowa 'cố $m$ ' jako 'zielony ryż' wydaje się mylące, gdyż może sugerować zieloną część rośliny. Przekład przy pomocy wyrażenia 'niedojrzały ryż' rodzi skojarzenia z ziarnem niejadalnym. Proponuję tłumaczenie jako 'ryż zielony' co kojarzy się z tym specyficznym gatunkiem i de facto jest takim.

Do wprowadzenia miłego nastroju w rozmowie w Europie podaje się alkohol w postaci piwa, wina, wódki w zależności od kraju. W Wietnamie rolę lekkiego narkotyku spełnia trầu cau 'betel' (liść betelu z kawałkiem kory $\mathrm{z}$ drzewka betelowego, posmarowane odrobiną wapna gaszonego 
i ćwiartką orzeszka palmy arekowej), będący typowym poczęstunkiem przy rozmowach. Porcje betelu żuje się powoli, a następnie wypluwa do specjalnego pojemniczka na stole, i bierze się kolejną porcję. Istnieje powiedzenie miếng trầu là đầu câu chuyện 'porcja betelu jest początkiem rozmowy'. Jest on do dziś, mimo rozpowszechnienia sie wódki ryżowej, tradycyjnie podawany na przykłąd w czasie zaręczyn.

Warunki klimatyczne oraz wcześnie zapadający zmrok sprzyjają spędzaniu czasu po pracy na wolnym powietrzu przy piwie $\mathrm{w}$ gronie kolegów. Charakterystyczna cechą jest zupełny brak pośpiechu. Do alkoholu podawane są zakąski, tak przyrządzone, że nie można ich zjeść szybko - nie do końca dopieczone, z kośćmi do obgryzania, itp. Na określenie takiego długiego wieczornego spotkania kolegów przy piwie z twardymi zakąskami rozpowszechnia się użycie słowa nhậu zaś w przypadku gdy jest również połączone z kolacją - nhậu lai rai 'popijanie i jedzenie'.

Inne elementy realioznawcze i kulturowe odnajdujemy w przysłowiach i idiomach opartych na innych skojarzeniach często związanych z rolnictwem i rybołówstwem np. lo bò trắng răng 'martwić się, żeby krowa miała białe zęby' co oznacza 'martwić się zupełnie niepotrzebnie' w myśl rozumowania, że krowa ma zawsze białe zęby. Ponadto w wielu tekstach występują odniesienia do baśni bądź legendarnych postaci z wietnamskiego i chińskiego obszaru kulturowego

Trudność $\mathrm{w}$ przekładzie sprawia także terminologia i wyrażania odnoszące się do zjawisk społecznych nieznanych w Polsce. Do takich zaliczam słowo hiếu, które $\mathrm{w}$ tekstach przeznaczonych dla odbiorcy dalekiego tłumaczymy jako szacunek lub szacunek dla starszych, w rzeczywistości to pojęcie dotyczy w pierwszej kolejności szacunku do rodziców. $\mathrm{W}$ języku wietnamskim istnieje słowo odpowiadające polskiemu rzeczownikowi 'szacunek' i jest to tôn trọng. Możemy również powiedzieć "tôn trọng người cao tuối" co będzie oznaczało właśnie 'szanowanie starszych ludzi'. Jednakże słowo hiếu jest czymś więcej. Przypisujemy temu słowu dwa znaczenia:

- żałobę po śmierci rodziców,

- szacunek dla rodziców, który przejawia się w następujący sposób: (i) posłuszeństwo, (ii) posiadanie potomka, (iii) opiekę nad rodzicami na starość, (iv) wyprawienie rodzicom pogrzebu, (v) urządzanie corocznych uroczystości z okazji rocznicy śmierci rodziców, dziadków i dalszych przodków.

Posłuszeństwo zaczyna się w wieku dziecięcym i nie kończy się nigdy. Istnieje powiedzenie bố me dặt đâu con ngồi đấy 'gdzie rodzice dziecko posadzą, tam ono siedzi'. Dotyczy to również $\mathrm{m}$. in. wyboru żony lub męża. Wyboru tego dokonują rodzice. Obecnie młodzi mają zagwarantowaną przez kodeks małżeński i rodzinny wolność wyboru małżonka i w praktyce coraz więcej wpływu na wybór swego życiowego partnera, jednak zasadniczo w dalszym ciągu to rodzice decydują, a małżeństwa wbrew woli rodziców nadal są rzadkością. 
Jeśli chodzi o posiadanie potomka najlepiej, gdy jest to chłopiec, jednak dziewczynki, w odróżnieniu do innych społeczeństw Azji są we Wietnamie bardzo cenione, zwłaszcza jako pierwsze dziecko. Funkcjonuje nawet powiedzenie: ruộng sâu trâu nái không bằng con gái đầu lòng 'głębokie pole i bawolica nie mogą się równać z pierworodną córką'. Wiąże się to ze znaną i w Europie prawdą, że dziewczynka już od najmłodszych lat jest pomocą dla matki przy prowadzeniu domu i opiece nad rodzeństwem, podczas gdy chłopcy bawią się w piłkę lub gry wojenne i pożytku w domu $\mathrm{z}$ nich nie ma.

Opieka nad rodzicami na starość to nuôi dưõng. Jest ona ściśle związana $\mathrm{z}$ terminem hiếu, w którym mieści się zapewnienie środków do życia rodzicom na starość i dbanie o ich zdrowie. Na określenie dziecka spełniającego te wymagania używamy słowa hiếu thảo 'szanujący rodziców', zaś osobę nie wykonującą lub lekceważącą te obowiązki nazywamy bất hiếu i jest to określenie zdecydowanie pejoratywne, możemy nawet powiedzieć, że obraźliwe i wydaje się, że właściwym tłumaczeniem byłby zwrot 'wyrodne dziecko'. Powszechny szacunek dla rodziców przenosi się w życiu społecznym w Wietnamie na starszych. Obserwujemy to na każdym kroku, choćby w autobusie, przy ustępowaniu miejsca (zjawisko w Polsce coraz rzadziej występujące). W Wietnamie, przy wejściu starszej osoby do środka komunikacji miejskiej, młodzi ludzie nie tylko wstają, robiąc miejsce, ale urządzanie corocznych uroczystości z okazji rocznicy śmierci rodziców, dziadków i dalszych przodków ale także pomagają starszej osobie przy zajmowaniu miejsca.

O ile w Polsce różne odłamy chrześcijaństwa stanowią ponad 90\% ludności, to w Wietnamie dominującą religią jest buddyzm, lecz udział buddystów szacuje się na ok 20\%, zaś wszystkie odłamy chrześcijaństwa razem wzięte stanowią poniżej 8\%. Pozostała część społeczeństwa jest bezwyznaniowa (ok 30-40\%) lub jest wyznawcami jakiejś $\mathrm{z}$ religii plemiennych. Cechą charakterystyczną Wietnamu jest powszechnie praktykowany, niezależnie od wyznawanej religii lub ateizmu, kult przodków. Nominalne chrześcijaństwo jest oczywiście przeciwne oddawaniu czci zmarłym, lecz prości rolnicy - chrześcijanie, na ołtarzykach prócz krzyża, portretu papieża Jana Pawła II, mają ustawione portrety przodków. $Z$ uwagi na to, że obrzędy i zwyczaje związane z tymi religiami są inne od katolickich, a więc nieznane w Polsce przy tłumaczeniu tekstów związanych z tą problematyką zazwyczaj dla odbiory dalekiego używa się określeń „święto religijne”, lub „na potrzeby kultu”. W tym punkcie chciałbym przybliżyć problematykę dwóch ważnych wydarzeń religijnych jakim są śluby i pogrzeby.

\section{1.Śluby}

Śluby odbywają się w domu przed ołtarzem przodków w obecności starszych z obydwu rodzin. Nowożeńcy zapalają kadzidełka nazywane thắp hưong oraz w modlitwie informują thông báo các cụ 'przodków' o zawarciu małżeństwa, a także wymieniają się obrączkami. Ślub jest 
poprzedzony spotkaniem obu rodzin w celu uzgodnienia szczegółów. Po tym wydarzeniu bliższa i dalsza rodzina zostaje powiadomiona o mającym nastąpić ślubie. Takie powiadomienie to dạng ngõ. Kilka tygodni później odbywa się uroczystość - ăn hỏi często tłumaczona jako 'zaręczyny', gdyż najbardziej zbliżónym funkcjonalnie zwyczajem polskim są rzeczywiście zaręczyny. Działanie ăn hỏi jest jednak inne, gdyż tak naprawdę po ăn hỏi młodzi są mężem i żoną. Należałoby więc tłumaczyć ăn hỏi jako 'nieoficjalny ślub'. Oficjalny ślub lễ cưới odbywa się kilka dni później, gdy do domu panny młodej przyjdzie swego rodzaju pochód weselny nazywany po wetnamsku đám cưới z panem młodym i starszymi rodu aby poprosić o ‘wydanie panny młodej' xin dâu. Po wydaniu panny młodej pochód weselny zaprowadza pannę młodą $\mathrm{w}$ drugim pochodzie o nazwie rước dâu do domu pana młodego lub jego rodziny, gdzie nowożeńcy będą mieszkać.

Ciekawym słowem związanym z tą tematyką jest $r a$ mắt w thumaczeniu literalnym 'przed oczy'. Powinniśmy to przetłumaczyć jako 'przedstawić' lecz dotyczy to tylko przedstawienia rodzinie i przodkom narzeczonego lub narzeczonej. $\mathrm{W}$ innych sytuacjach do przedstawiania jednej osoby innym osobom używamy czasownika giói thiệu 'przedstawić'.

\subsection{Pogrzeby}

Zwyczaje pogrzebowe we Wietnamie różnią się bardzo od polskich, stąd wiele trudnych do przetlumaczenia pojęć. Po śmierci $\mathrm{w}$ domu zmarłego gromadzi się rodzina i znajomi oraz sąsiedzi zmarłego, zapalają kadzidełka i modlą się w intencji szczęśliwego zakończenia cierpień, i wyzwolenia z życia, gdyż życie jest jednym cierpieniem sinh-lão-bệnh-tử 'narodziny-starość-choroba-śmierć', oraz składają na ołtarzyku dary: potrawy, alkohol, lub kopertę z pieniędzmi. Ten obrządek ma nazwę phúng viếng co możemy przetłumaczyć jako 'czuwanie przy zmarłym'. W dniu pogrzebu orszak pogrzebowy odprowadza zmarłego na cmentarz gdzie zostaje pochowany w drewnianej trumnie. Następnie odbywa sie 'uroczystość pogrzebowa' lễ an táng. Po 49 dniach od pogrzebu odbywa się uroczystość thất thất lai tuần, która ma na celu definitywne pożegnanie duszy zmarłego, która do tego czasu znajdowała się częściowo w krainie umarłych, częściowo była jeszcze związana ze swoją rodziną i domem. Co roku należy obchodzić giỗ 'rocznicę śmierci' członków rodziny (zakłada się, że istnieje taki obowiązek do piątego pokolenia). Giỗ jest radosną okazją do spotkania się całej rodziny, wszyscy cieszą się że zakończyły się trudy zmarłego i nic złego juz go nie spotka. Po trzech latach od śmierci następuje 'ekshumacja' bốc mộ, następuje czyszczenie wszystkich kosteczek zmarłego i umieszczenie ich w porcelanowej trumnie, oraz przewiezienie w miejsce ostatecznego spoczynku. Często tym miejscem jest pole, które było własnością zmarłego. W odróżnieniu do religii chrześcijańskich nie oczekuje sie tutaj zmartwychwstania, jest natomiast silna wiara w 'reinkarnację' luân hồi.

Aby pobudzić zmarłego do przejścia w następne wcielenie niektóre mniejszości narodowe ozdabiają miejsce pochówku figurami kobiet 
w zaawansowanej ciąży lub figurkami mężczyzn i kobiet w trakcie aktu płciowego.

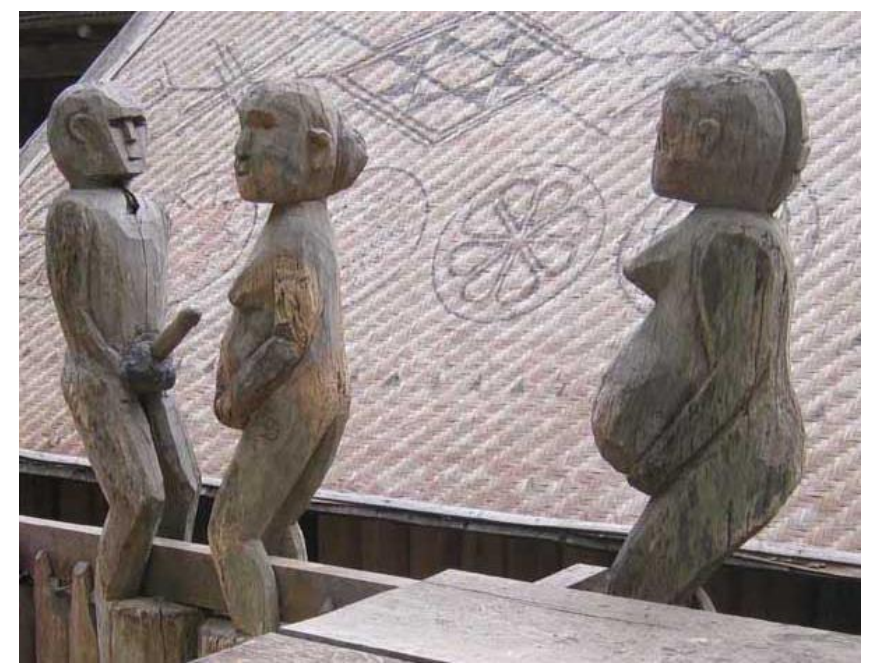

\subsection{Przykładowe terminy zanurzone kulturowo z dziedziny prawa}

Podczas tłumaczenia tekstów wietnamskich związanych $\mathrm{z}$ prawem spadkowym lub prawem matrymonialnym występują słowa określające pojęcia, których nie ma w języku polskim. Jednym z takich pojęć jest thờ cúng. Znajdujemy to słowo np. w artykule 648 pkt 3. kodeksu cywilnego:

Dành một phần tài sản trong khối di sản để di tặng, thờ cúng

Przeznaczyć część majątku masy spadku na darowizny pośmiertne i ceremonie kultu przodków.

Poszczególne słowa w zdaniu przetłumaczymy w następujący sposób:

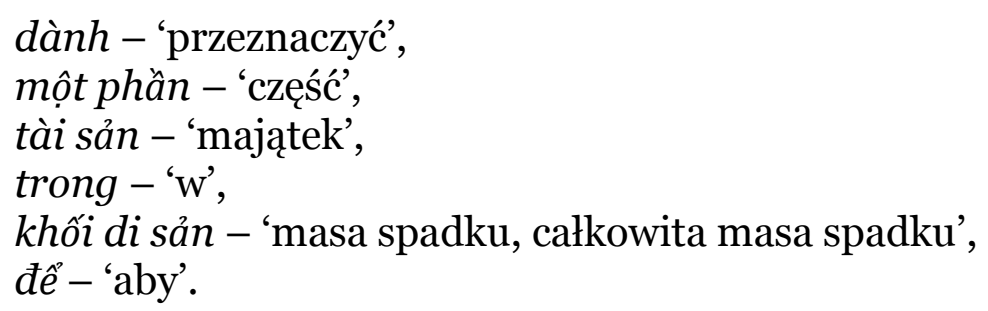

Kolejne dwa słowa di tặng i thò̀ cúng wymagają dodatkowych objaśnień. Słowo di tặng zawiera morfem tặng 'podarować' oraz morfem di, który występuje jako samodzielne słowo w znaczeniu 'przemieścić', natomiast jest składnikiem wielu słów, np.:

di cảo - nieopublikowane rękopisy zmarłego,

di ảnh - zdjęcie zmarłego (do postawienia na ołtarzyk),

di chúc - testament,

di cốt - kości umarłego lub wykopaliska prehistorycznych zwierząt, 
di tích - pamiątki z przeszłości, zabytki,

di sản - masa spadku (zwróćmy uwagę na powiązania ze słowem tài sản 'majątek'),

di chuyển - przemieszczać,

di động - przemieszczający się, przenośny, obecnie również jako 'telefon komórkowy'.

$\mathrm{W}$ związku $\mathrm{z}$ tym di tặng powinniśmy przetłumaczyć na 'prezent pośmiertny' lub używając języka prawniczego 'darowizna pośmiertna'.

Szerszego wyjaśnienia wymaga słowo thò̀ cúng. Pierwszy morfem thò' ma 2 znaczenia: 'czcić ,wyrażać szacunek' lub 'oddawać cześć duchom, odprawiać nabożeństwo, modlić się. Morfem ten odnajdziemy np. w wyrazach:

$$
\begin{aligned}
& \text { bàn thò - ołtarz, } \\
& \text { cái bàn - stół, } \\
& \text { nhà thò̀- kościół, } \\
& \text { cái nhà - dom. }
\end{aligned}
$$

Drugi morfem cúng występuje w dwóch znaczeniach: (i) składać ofiary dla zmarłych przodków, (ii) trwonić majątek. W interesującym nas znaczeniu spotkamy ten morfem w następujących wyrazach:

cúng lễ - uroczystość składania ofiary dla przodków w rodzinie, cúng giỗ - składanie ofiary z okazji rocznicy śmierci, cúng tế - składanie ofiar duchom np. duchowi ziemi, duchowi nieba, thầy cúng - mistrz ceremonii składania ofiary przodkom, cúng tổ tiên - składanie ofiar przodkom.

Wyraz thò̀ cúng oznacza więc 'odprawianie ceremonii składania ofiar przodkom' lub w wersji skróconej ‘ceremonię kultu przodków'.

Ceremonie kultu przodków można podzielić na dwie grupy:

a) ceremonia ku czci przodków rodziny lub rodu nazywaną cúng lễ,

b) ceremonia ku czci słynnych bohaterów narodowych cúng tổ tiên (słowo tổ tiên oznacza 'przodkowie' i jest w nim obecny morfem tổ 'gniazdo'). W Wietnamie oddaje się cześć twórcy pierwszego państwa wietnamskiego, legendarnemu królowi Hùng, a także licznym bohaterom narodowym z odległej i nieodległej przeszłości. Ceremonie te nie mają charakteru ustalonego rytuału na podobieństwo katolickiej mszy św. lecz odprawiane są indywidualnie, bez udziału mnichów, polegają na złożenia na ołtarzu owoców, potraw, alkoholu, słodyczy i zapaleniu 'trociczek, kadzidełek' hưong oraz na modlitwie. 


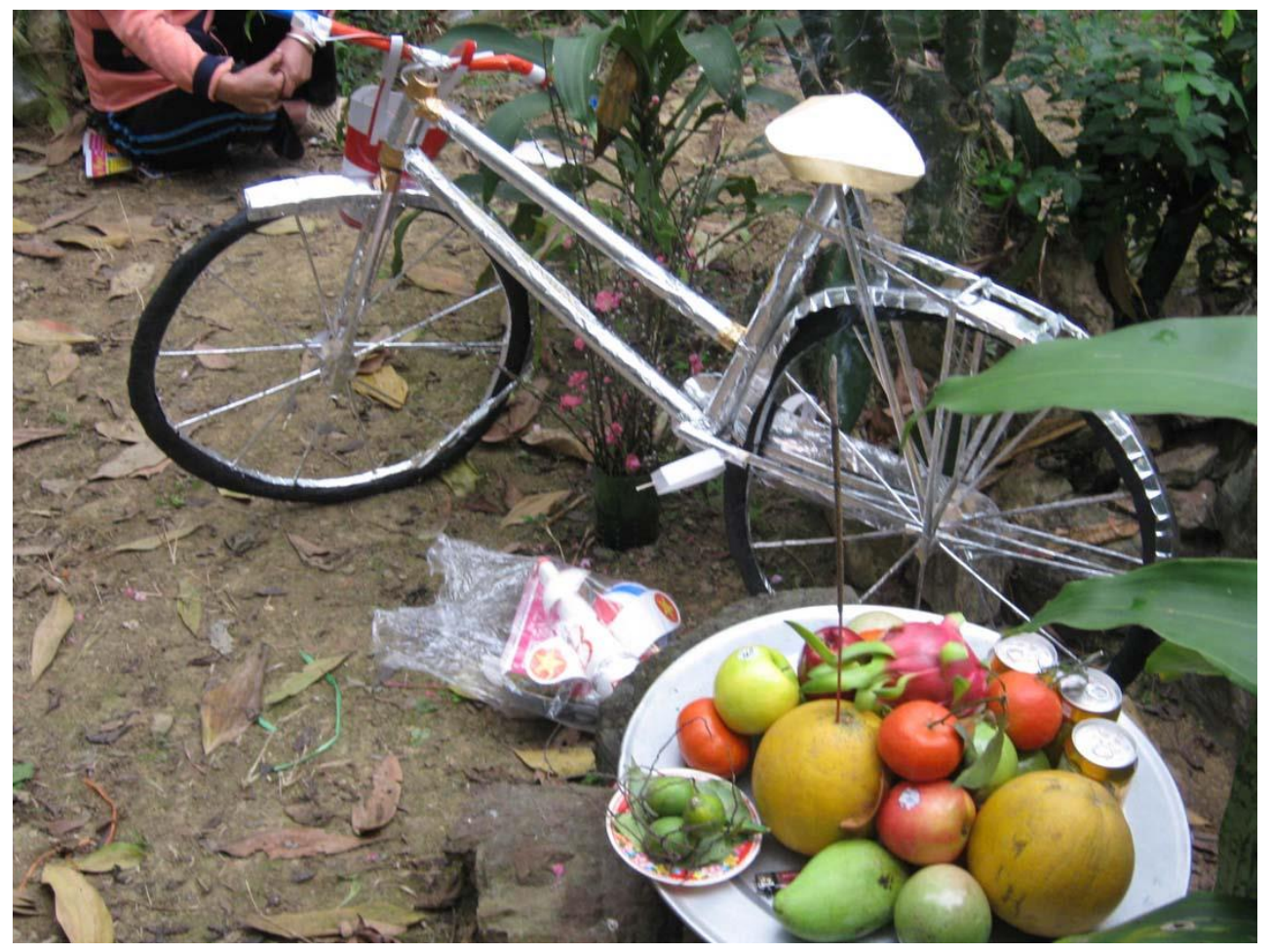

W przypadku ceremonii ku czci bohaterów państwowych na ołtarzu należy złożyć również ofiarę z pieniędzy.

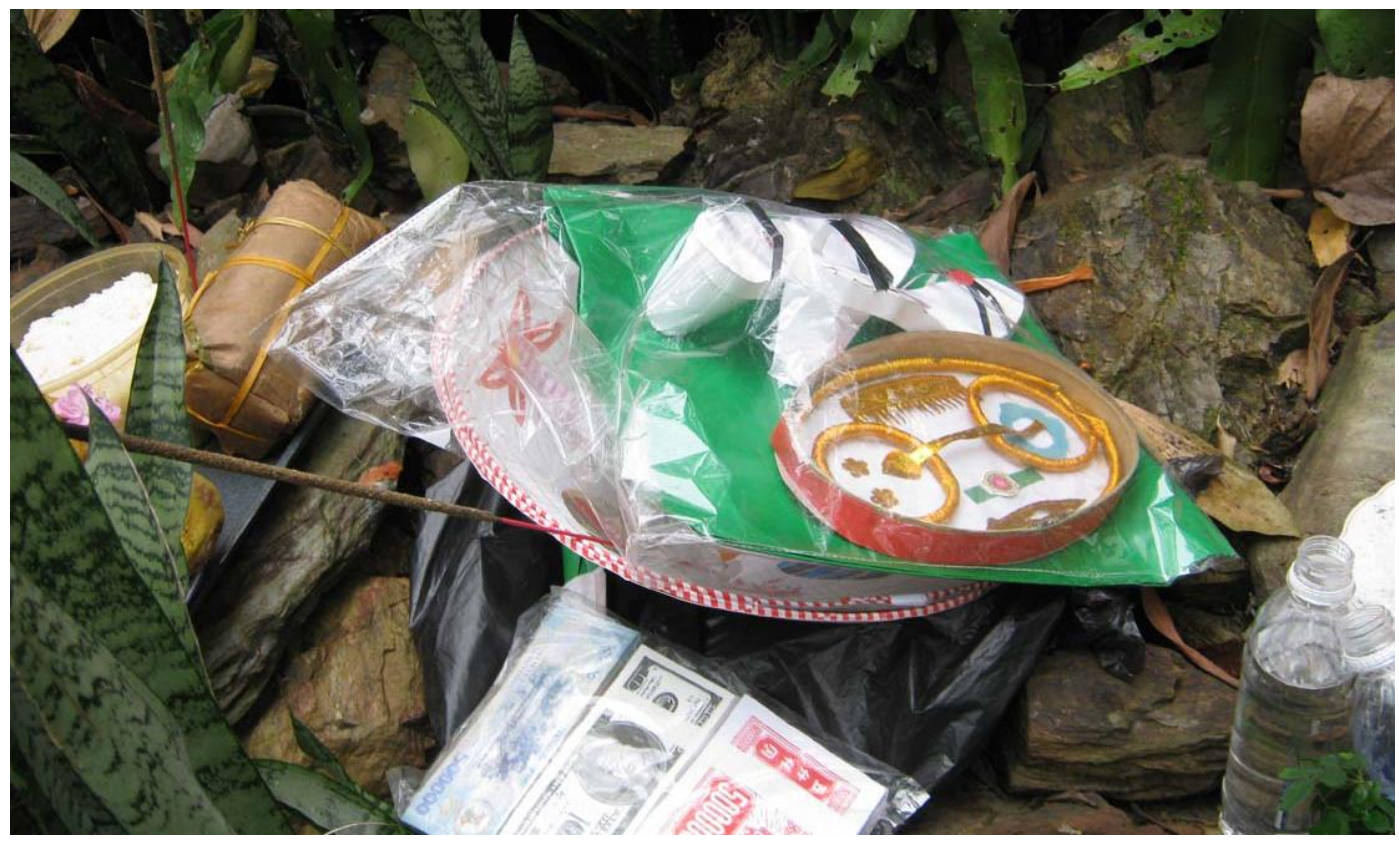

Po wypaleniu kadzidełek osoby oddające cześć przodkom zabierają dary ze sobą do domu (pieniądze pozostają na potrzeby świątyni), gdzie zostaną w gronie rodzinnym spożyte. Uroczystości ku czci przodków rodziny gromadzą rodzeństwo, dzieci, wnuków, prawnuków zmarłego i po 
zapaleniu kadzidełek spala się również specjalne ofiarne pieniądze, oraz przedmioty z papieru - domy, samochody, buty z których po spaleniu będzie korzystał zmarły w zaświatach.

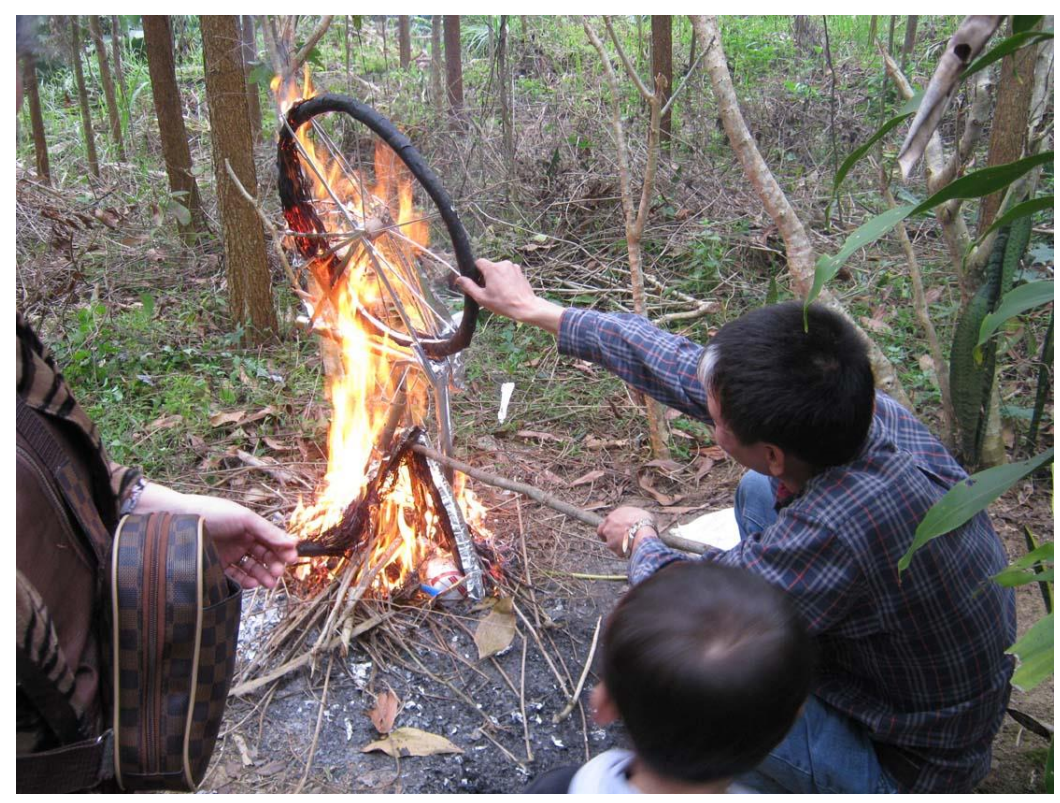

Po zakończeniu uroczystości, każdy z uczestników otrzyma dar - część artykułów spożywczych z ołtarzyka.

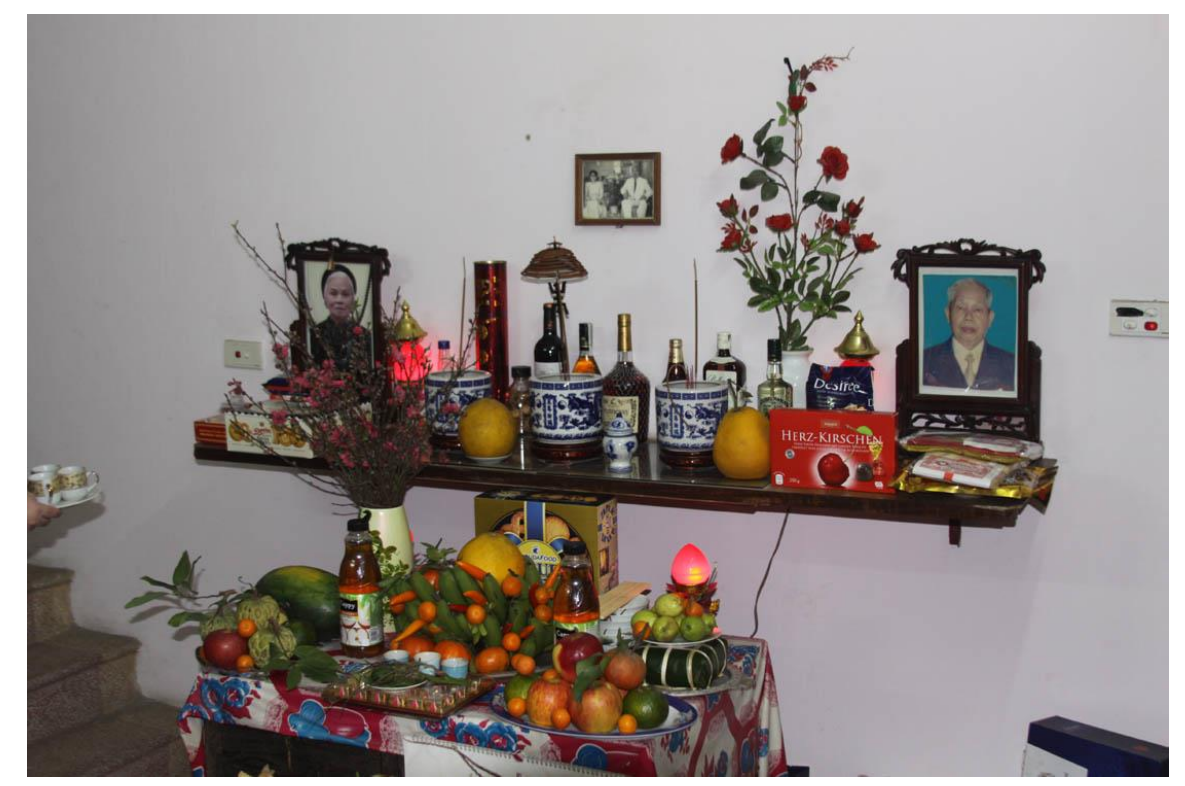

W kodeksie cywilnym znajdujemy też terminy, wymienione powyżej, które posiadają odpowiedniki w języku polskim, lecz kryje sie za nimi nieco inna treść. $Z$ przytoczonych wyjaśnień na temat religii wiemy, że mai táng 'pogrzeb' jest tylko pogrzebem tymczasowym. Drugi pogrzeb określa się 
słowem bốc mộ thay áo 'ekshumacja zmiana trumny'. Ciekawostką jest tutaj morfem áo 'koszula', który występuje w słowie áo quan 'trumna'

Sylaby tiền cấp dưỡng 'alimenty' oraz tiền trợ cấp 'zapomoga' są elementami języka prawa i mają odpowiedniki w języku polskim. Zobaczmy z jakich morfemów składają się wietnamskie terminy. W obu słowach występuje morfem tiền 'pieniądze'. W obu słowach występuje także morfem cấp, który może wystąpić w pięciu znaczeniach, w obu słowach występuje jednak w tym samym znaczeniu: 'zaopatrywać'.

Morfem dướng ma znaczenie 'karmić, wychowywać' i może występować np. w słowie kem dương da 'krem odżywczy'. Słowo cấp dưỡng ma w jęz wietnamskim dwa znaczenia: 'okazać pomoc materialną' i drugie 'przygotowywać jedzenie, gotować'. Słowo alimenty w tłumaczeniu bliskiemu do oryginału jawi nam sie jako wyrażenie 'zaopatrzenie w pieniądze wcelu wychowania'.

W słowie tiền trợ cấp 'zapomoga' występuje morfem trọ' 'pomagać', który nie tworzy samodzielnego słowa. Tworzy on słowo trợ cấp ['okazć materialną pomoc] . Słowo [zapomoga] w tłumaczeniu bliskim oryginałowi jest więc wyrażeniem: [pieniądze dla okazania pomocy]

W wietnamskim kodeksie Luật hôn nhân và gia đình 'Prawo małżeńskie i rodzinne’ znajdujemy art. 11 par. 2. o następującej treści:

Chính phủ quy định việc đăng ký kết hôn ở vùng sâu, vùng xa.

Rząd określi zasady rejestracji małżeństw w regionach mniejszości narodowych.

Taki zapis wymaga kilku wyjaśnień. Wyrażenie vùng sâu, vùng xa zbudowane jest z następujących elementów składowych:

vùng - 'rejon, strefa, obszar',

sâu - 'głęboki',

$x a$ - 'odległy, daleki'.

Jako całość wyrażenie takie oznacza 'odległe regiony', jednak ustawodawca ma na myśli 'mniejszości narodowe' dân tộc thiểu số. Zapis w artykule 11 mówi, że dla mniejszości narodowych zostaną ustalone odrębne przepisy i zasady dokumentowania zawartego małżeństwa. Do lat pięćdziesiątych $\mathrm{XX}$ wieku w Wietnamie nie prowadzono rejestracji małżeństw przez administracje państwową i istniało legalne wielożeństwo. Zawarcie małżeństwa następowało przed rodzinnym ołtarzem przodków, jako wynik porozumienia między rodzinami nowożeńców. Jeżeli rodzina panny młodej uznała, że narzeczony jest wystarczająco zamożnym człowiekiem i może utrzymać kilka żon (w praktyce do czterech) wydawano córkę za mąż, jako kolejną żonę. Rodziny z pobudek materialnych chętnie wydawały córki za mandarynów lub innych dostojników, jednak same kolejne żony uskarżały się na taki los. Znane jest powiedzenie chết trẻ còn hơ lấy lẽ 'lepiej umrzeć za młodu niż zostać kolejną żoną'. 
Bogdan Nowicki: Terminologia zanurzona ...

\section{Podsumowanie}

Podsumowując, różnice językowe (fonetyczne i gramatyczne) oraz kulturowe $\mathrm{w}$ istotny sposób wpływają na proces przekładu, mogąc niedoświadczonego tłumacza zwieść na manowce. By móc skutecznie tłumaczyć teksty z języka wietnamskiego na polski konieczna jest dogłębna znajomość kultury i realiów obu obszarów językowych, gdyż bez niej poprawne zrozumienie komunikatu w wielu przypadkach jest niemożliwe. 


\section{Bibliografia}

Trọng Báu, Nguyễn. 2012. Phong tục tập quán và lễ hội của người Việt. Hà Nội: Văn hóa Thông tin.

Việt, Tân. 1994. Một trăm điều nền biết về phong tục Việt Nam. Hà Nội: Nhà Xuất bản Văn hóa Dân tộc.

Ánh Toan. 1998. Phong tục thờ cúng trong gia đình Việt Nam. Đồng Tháp: Nhà Xuất bản Đồng Tháp

Hồng, Ánh. 2004. Tín ngương phong tục và nhũng kiêng kỵ dân gian Việt Nam. Thanh Hóa: Nhà Xuất bản Thanh Hóa. 